\title{
Assessment of Ground Water Quality in and around Pydibhimavaram Industrial Area, AP, India
}

\author{
Venkata Rao Gummadi and Kalpana Polipalli
}

\begin{abstract}
In recent days ground water quality is deteriorating at alarming rate due to increased industrial activities. This study assessed the water quality of 30 samples collected from 4 locations of Pydibhimavaram industrial area. An investigation was carried out by collecting a total of 30 ground water samples for three seasons in study area to assess the ground water quality for its suitability for agriculture and domestic purpose. This study focused on variation of water quality parameters with reference to water level fluctuations. The well reduced levels were determined with the help of total station and these levels are connected to the mean sea level. Ground water levels from the well top surface were measured using water level indicator. Water quality parameters such as pH, total hardness, chlorides $(\mathrm{Cl})$, iron $(\mathrm{Fe})$, electric conductivity (E.C), sulphates $\left(\mathrm{SO}_{4}{ }^{2-}\right)$, nitrates $\left(\mathrm{NO}_{3}{ }^{-}\right)$, cadmium $(\mathrm{Cd})$, lead $(\mathrm{Pb})$, nickel $(\mathrm{Ni})$ and zinc $(\mathrm{Zn})$ were analyzed. These parameters were estimated using standard procedures and the results were compared with environmental quality standards. The results indicated that the water quality of the study area exceed the permissible limits of standards. This showed that the ground water of the study area was contaminated due to the industrial effluents.
\end{abstract}

Index Terms-Water quality, assessment, heavy metals, industrial area, ground water levels.

\section{INTRODUCTION}

Water is nature's most wonderful, abundant and useful compound. Clean safe and adequate fresh water is vital to the survival of all living organisms and the smooth functioning of ecosystems, communities and economies. Water is not only essential for the lives of animals and plants, but also occupies a unique position in industries. The fresh water present on the earth is only $2.8 \%$ out of all the waters on the earth and out of that $0.03 \%$ of fresh water is readily available for drinking and other purposes in the form surface water and ground water. In the last few decades, there has been a tremendous increase in the demand for fresh water due to rapid growth of population and the accelerated pace of industrialization. Ground water is the major source of drinking water in both urban and rural areas and it is also an important source for the industrial and agriculture sectors [1]. Water quality is of significant importance of water uses [2]. Ground water quality in a region is largely influenced by both natural processes and by manmade inputs. Ground water pollution with physical,

Manuscript received July 2, 2015; revised September 23, 2015.

G. Venkata Rao is with the Department of Civil Engineering, GMR Institute of Technology, Rajam-532 127, India (tel.: 08941-251593, e-mail: venkatarao.g@gmrit.org).

P. Kalpana is with the Department of Chemical Engineering, GMR Institute of Technology, Rajam-532 127, India (e-mail: kalpana.p@gmrit.org) chemical and biological contaminants by anthropogenic activities is of great environmental attention all over the world. The discharge of domestic waste, solid waste and industrial effluents causes the ground water pollution [3]. Due to these the water changes its properties. The monitoring of water quality is one of the major tools for sustainable development and provides important information for water management. Ground water pollution not only affects the water quality but also threats human health, economic development and social prosperity. The problem associated with the quality of water is a topic of prime importance in the world and getting popularity for research purposes. Therefore, it is necessary to examine the quality of ground water and knowledge of extent of pollution become essential in order to preserve the valuable sources of water for future generations. Thus, in this paper an attempt has been made to assess the physic-chemical properties of ground water of the Pydibhimavaram Industrial area.

\section{STUDY AREA}

The present study is conducted in Pydibhimavaram area, Ranasthalammandalam, Srikakulam District, Andhra Pradesh. It is situated between $18.145 \mathrm{~N} 83.627 \mathrm{E}$ and $18.099 \mathrm{~N}$ 83.674E Latitudes and Longitudes . The area is recognosed as aIndusrial area by the Government of India. Many Industries viz. Andhra Organics, Dr.Reddy's Laboratories, Aurobindo, United breweries are situated in the Pydibhimavaram. The area is cultivated in 20 Sq.km and solely dependent on the ground water. study area covers the villages like Pydhibeemavaram, Boyapalem, Akkayyapalem, Naruva and Mentada as shown in Fig.1. The chemical and pharmaceuticals industries located near this area and discharge their effluent on the low lying areas and in river water. Which is leads to the ground water pollution around the area. The present study is to assess the water quality by using the various physical, chemical, biological parameters in that industrial area. A large number of bore wells and open wells based spread over the area selected for the study and the water quality has been assessed for both dry and wet seasons over a period of 3 months. The assessment has been done with respect to common water quality parameters like chloride, hardness, ph, electrical conductivity, nitrites, sulphates, dissolved oxygen, chemical oxygen demand, biochemical oxygen demand and heavy metals.

\section{METHODOLOGY}

\section{A. Reconnaissance Survey of Study Area}

First a preliminary visit was carried out to all those regions 
around Pydibeemavaram industrial belt of Srikakulam district. Interaction with the local people of each area helped in finding out the regions which are much affected by ground water pollution. Based on these, our study area, Pydibeemavaram i.e. ranasthalammandalam of Srikakulam district was established as shown in Fig. 1.

\section{B. Identification of Wells}

Some of the wells in each area were identified with the help of the local people. An approximate of 50 wells was chosen in each region (village) of the study area. All the wells which are chosen for the study purpose are identified and labelled with appropriate numbers. At each of the identified wells, the latitude and longitude of the location is found out by using a GPS instrument of that particular well where the sample is collected and wells in the study area as shown in Fig.1.

\section{Determination of Elevations of the Study Area}

Survey was conducted for knowing the elevation of each and every study well by using Total station survey procedure.

\section{Collection of Water Samples}

Thirty ground water samples were collected randomly selected from study area in the months of November, December\& January (winter) with all precautions and preserved .For sampling, bore wells, pumps were permitted to flow for more than $10 \mathrm{~min}$ and required quantity of water was collected in pre-cleaned polythene containers. After identification and demarcation of each study well, every sample was marked with appropriate number to tally with location of sample where it has been collected.

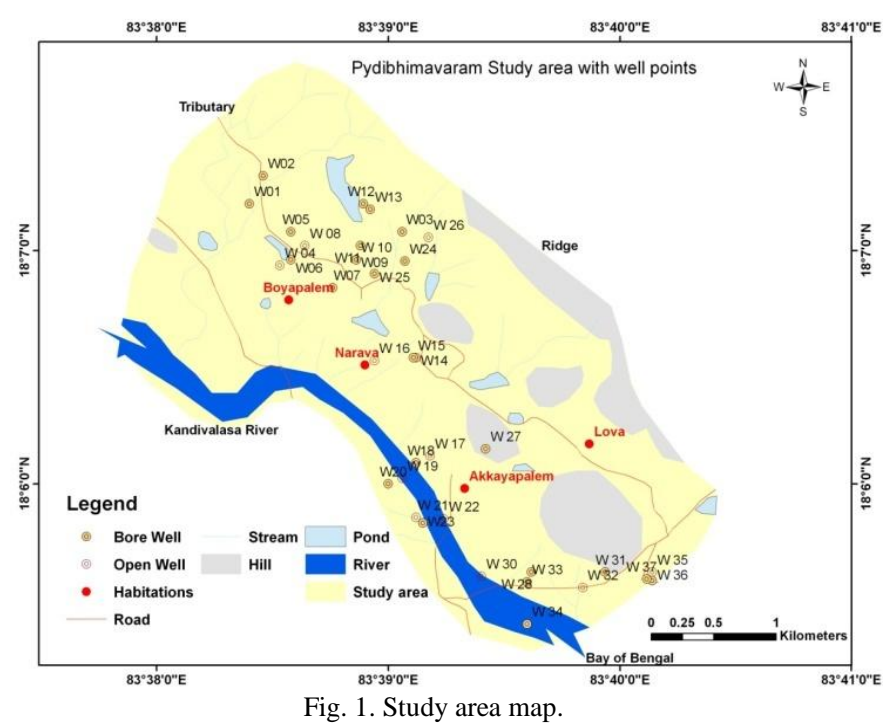

\section{E. Determination of the Water Level of the Wells}

The water level of each and every well was determined using water level indicator.

\section{F. Sampling and Analysis of Water Samples}

Water samples were collected using spot sampling procedure [4] in previously washed and dried polythene containers from in and around areas of Pydibhimavaram. The samples were put to examination in the laboratory to analyze some physical and chemical parameters. These include colour, odour, temperature, $\mathrm{pH}$, electrical conductivity, chloride, hardness, nitrites, sulphates, heavy metals viz., Cd, Zn, Fe. The analysis of water samples was done using standard procedure [5] and all analysis was done in triplicate.

\section{RESUlTS AND DISCUSSION}

\section{A. Water Levels Flucuations in Bore Wells and Open Wells}

Samples are collected from bore wells and open wells at different water levels in three months i.e. in November, December and January (winter). These water samples are tested for physic- chemical parameters. The water level fluctuations in winter season were tabulated in Table I. These Figures indicated that the depths of water in the open wells and bore wells decreased with time that is from November to January. The water levels decreased slightly high in open wells compared to bore wells. This decrease in water level may be due to extraction of water from bore wells and due to exposure to atmosphere in open wells along with water extraction. The results revealed that the water level changes in wells are high in Boyapalem (W01, W02, W03, W05, W06, W07, W09, W11, W12,W13, W24, W25) than compared to Akkayyapalem (W18, W20, W21, W22, W23, W27, W28 ) and Mentada (W35, W36, W37, W38) of study area and water level fluctuations are low with time at Naruva (W14, W15) in the study area.

\section{B. Water Quality Parameters}

The discussion of variation of water quality parameters during November, December and January months is given in the following paragraphs.

Water $\mathrm{pH}$ is one of the most important aspects of water quality. Chemical and biological reactions are directly dependent upon the $\mathrm{pH}$ of water system. The $\mathrm{pH}$ of ground water obtained in range from 7.01 to 8.12 . The acceptable limit for the drinking water standard is $6.5-8.5$ as prescribed by 'WHO', 1996 [6]. The results showed that all the samples are within permissible limits. The $\mathrm{pH}$ of water samples in bore wells is higher in November month compared to December and January where as the $\mathrm{pH}$ of some open wells are higher in December and January than that of the November month

Electrical conductivity is a measure of water capability to transmit electric current and also it is a tool to assess the purity of water. The electrical conductivity in the water samples as an indication of dissolved ions. In the present work conductivity of ground water samples are in the range from 521.00 to $2589.00 \mathrm{mhos} / \mathrm{cm}$, all the water samples are found to be well above the permissible limit (300 mhos/cm) as per WHO. The higher values of EC indicate the sample contains higher levels of dissolved ions [7].

The Water Hardness Classification, according to WHO, 2004 [8] follows this criteria; Soft (0-50mg CaCO3/L), Moderate Soft $(50-100 \mathrm{mg} \mathrm{CaCO} / \mathrm{L}, \quad$ Slightly Hard (100-150mg CaCO3/L), Moderate Hard (150-200 mg $\mathrm{CaCO} 3 / \mathrm{L})$, Hard (200-300 mg CaCO3/L) and Very Hard (over 300mg CaCO3/L). Total hardness (TH) for the samples were found in the range of 139.3 to $1136.4 \mathrm{mg} / \mathrm{L}$. From the WHO 2004 classification, the groundwater samples analyzed were slightly hard to very hard. The results indicated that the 
wells W13 ,W14, ,W15 ,W23, ,W28, $\mathrm{W} 33$,W16,W17, W26,W32, and W34 which exceeds the permissible limits.

The concentration of chloride in the groundwater samples ranged from 40.89 to $690.45 \mathrm{mg} / \mathrm{L}$. The amount of chloride ions recommended being acceptable by WHO (1996) [6] is within $10-250 \mathrm{mg} / \mathrm{L}$. The results indicated that very few samples (W28, W29 and W31) exceed the permissible limit. This may be due to groundwater contamination as a result of seepage from septic systems, landfill, fertilizers or animals [7]. Nitrite contents are found to be ranging from 0.0012 to 1.373 ppm. The desirable limit for nitrite is $0.02 \mathrm{mg} / \mathrm{L}$. Nitrite concentrations over $1 \mathrm{mg} / \mathrm{l}$ should not be used for infant feeding. Nearly $90 \%$ of the samples exceed the permissible limits. The nitrite concentration in bore wells is almost same in all the months, similar case in open wells except in some wells.

TABLE I: WATER LeVel MEASUREMENT With ReFERENCE to MEAN SEA LeVEL

\begin{tabular}{|c|c|c|c|c|c|c|c|}
\hline \multirow{2}{*}{ S.No } & \multirow{2}{*}{ Map notation } & \multirow{2}{*}{ Latitude } & \multirow{2}{*}{ Longitude } & \multirow{2}{*}{$\begin{array}{l}\text { Reduced Level } \\
\text { (MSL) }\end{array}$} & \multicolumn{3}{|c|}{ Water level from MSL } \\
\hline & & & & & Nov & Dec & Jan \\
\hline \multicolumn{8}{|c|}{ Bore Wells } \\
\hline 1 & W01 & 18.1200 & 83.6400 & 20.432 & 16.53 & 14.63 & 14.13 \\
\hline 2 & W02 & 18.1220 & 83.6410 & 18.330 & 14.61 & 12.03 & 11.91 \\
\hline 3 & W03 & 18.1180 & 83.651 & 19.887 & 16.30 & 13.48 & 13.35 \\
\hline 4 & W05 & 18.1180 & 83.6430 & 17.758 & 13.76 & 10.15 & 08.15 \\
\hline 5 & W06 & 18.1160 & 83.6430 & 15.874 & 11.87 & 08.45 & 06.77 \\
\hline 6 & W07 & 18.1140 & 83.6460 & 18.286 & 14.21 & 10.93 & 09.68 \\
\hline 7 & W09 & 18.1160 & 83.6477 & 18.888 & 15.93 & 12.68 & 10.68 \\
\hline 8 & W11 & 18.1170 & 83.6480 & 25.043 & 22.05 & 18.24 & 17.94 \\
\hline 9 & W12 & 18.1200 & 83.6482 & 14.860 & 11.80 & 07.30 & 07.14 \\
\hline 10 & W13 & 18.1196 & 83.6487 & 17.176 & 14.07 & 09.11 & 08.96 \\
\hline 11 & W14 & 18.1090 & 83.6520 & 18.755 & 15.50 & 10.40 & 10.10 \\
\hline 12 & W15 & 18.1090 & 83.6518 & 18.104 & 14.80 & 10.25 & 09.39 \\
\hline 13 & W18 & 18.1015 & 83.6520 & 09.879 & 05.97 & 03.01 & 02.67 \\
\hline 14 & W20 & 18.1000 & 83.6500 & 14.528 & 10.42 & 08.74 & 08.22 \\
\hline 15 & W23 & 18.0972 & 83.6525 & 16.317 & 13.11 & 12.73 & 12.53 \\
\hline 16 & W24 & 18.1159 & 83.6512 & 19.120 & 16.23 & 15.61 & 15.40 \\
\hline 17 & W 25 & 18.1150 & 83.6490 & 19.887 & 16.86 & 16.35 & 16.20 \\
\hline 18 & W 27 & 18.1025 & 83.6570 & 15.649 & 12.52 & 12.16 & 12.02 \\
\hline 19 & W 28 & 18.0937 & 83.6603 & 06.713 & 03.63 & 03.29 & 03.12 \\
\hline 20 & W 31 & 18.0937 & 83.6656 & 12.698 & 09.52 & 04.27 & 04.07 \\
\hline 21 & W 33 & 18.0930 & 83.6600 & 12.988 & 10.18 & 04.82 & 04.60 \\
\hline 22 & W 34 & 18.0900 & 83.6600 & 11.773 & 08.67 & 03.49 & 03.36 \\
\hline 23 & W 36 & 18.0931 & 83.6690 & 13.718 & 11.11 & 05.52 & 05.40 \\
\hline 24 & W 37 & 18.0932 & 83.6686 & 14.194 & 11.29 & 06.13 & 05.98 \\
\hline 25 & W 38 & 18.1063 & 83.6890 & 14.408 & 11.35 & 06.80 & 06.42 \\
\hline \multicolumn{8}{|c|}{ Open wells } \\
\hline 26 & W 04 & 18.1156 & 83.6422 & 16.120 & 13.02 & 10.87 & 10.30 \\
\hline 27 & W 08 & 18.1170 & 83.6440 & 19.134 & 15.08 & 11.46 & 09.24 \\
\hline 28 & W 10 & 18.1160 & 83.6477 & 18.170 & 15.27 & 11.93 & 09.67 \\
\hline 29 & W 16 & 18.1088 & 83.6490 & 15.890 & 12.56 & 07.20 & 07.17 \\
\hline 30 & W 17 & 18.1020 & 83.6530 & 12.560 & 08.06 & 03.58 & 02.76 \\
\hline 31 & W 19 & 18.1004 & 83.6510 & 14.424 & 11.71 & 11.61 & 11.09 \\
\hline 32 & W 21 & 18.0976 & 83.6520 & 14.065 & 11.22 & 10.85 & 09.96 \\
\hline 33 & W 22 & 18.0975 & 83.6540 & 16.098 & 13.14 & 12.48 & 12.13 \\
\hline 34 & W 26 & 18.1176 & 83.6529 & 26.297 & 23.19 & 22.87 & 22.68 \\
\hline 35 & W 29 & 18.0926 & 83.6505 & 04.869 & 01.75 & 01.50 & 01.15 \\
\hline 36 & W 30 & 18.0934 & 83.6567 & 04.067 & 00.95 & 00.53 & 00.21 \\
\hline 37 & W 32 & 18.0926 & 83.6640 & 13.328 & 10.12 & 04.98 & 04.79 \\
\hline 38 & W 35 & 18.0937 & 83.6690 & 14.343 & 12.34 & 06.44 & 06.05 \\
\hline
\end{tabular}

Sulfate can be found in almost all natural water. The samples contain the sulphate concentration in the range of 71.90 to $517.944 \mathrm{mg} / \mathrm{L}$. The desirable limit for sulphate is 200 $\mathrm{mg} / \mathrm{L}$ and the permissible limit in the absence of alternate source is $400 \mathrm{mg} / \mathrm{L}$. The wells which exceed permissible limits are W23, W33, and W34. This may be due to groundwater contamination as a result of industrial wastes.

Rapid industrialization results more effluents discharged in various water resources. These effluents are usually treated by physicochemical treatment followed by biological treatment process. However, such treatment systems are not effective for removal of color, dissolved solids, trace metals, etc. The effluents containing trace metals, when discharged on agricultural land for irrigation, increase the metal content of the soils and availability of metals to plants. Trace metals are widely distributed in the environment with sources mainly from weathering of minerals and soils [9], [10] (Merian, 1991; O’Neil, 1993). However, inputs from anthropogenic activities have increased the levels in the environment tremendously [11], [12]. Some of the metals are of concern because of their toxicity to plant $(\mathrm{Zn})$ while others $(\mathrm{Cd}, \mathrm{Pb}, \mathrm{Ni}, \mathrm{Fe})$ are hazardous to human health. 
The concentration of $\mathrm{Zn}$ in the water samples ranged from 0.01 to $0.4 \mathrm{mg} / \mathrm{l}$. The permissible limit of $\mathrm{Zn}$ concentration in drinking water is $5.0 \mathrm{mg} / \mathrm{l}$ (WHO, 2004) [8]. It was observed from the data that all the samples were below the permissible limit of WHO. Beyond this limit it can cause astringent taste and opalescence in water.

Concentration of $\mathrm{Ni}$ varied between 0.01 and $0.07 \mathrm{mg} / \mathrm{L}$ from the analysis. The desirable limit for $\mathrm{Ni}$ is $0.02 \mathrm{mg} / \mathrm{l}$ for drinking water (WHO, 2004). The concentration of iron in the samples ranged from 0.01 to $0.2 \mathrm{ppm}$, except for bore well W $31(0.8900 \mathrm{mg} / \mathrm{lt})$ and open well W $32(0.5790 \mathrm{mg} / \mathrm{lt})$. This result indicated that bore well 31 and open well 32 were contaminated with $\mathrm{Fe}$. The concentration of $\mathrm{Pb}$ inwater samples ranges from 0.04 to $0.119 \mathrm{mg} / \mathrm{l}$. Thepermissible limit of $\mathrm{Pb}$ concentration in drinking water is $0.01 \mathrm{mg} / \mathrm{l}$ (WHO, 2004).

The results revealed that most of the samples are above the permissible limit. High $\mathrm{Pb}$ concentration was observed in ground water samples collected from Pydibheemavaram industrial area. All the samples analyzed for $\mathrm{Cd}$ in water samples fell within the WHO (2004) recommended limits of $0.01 \mathrm{mg} / \mathrm{L}$ for $\mathrm{Cd}$ in drinking water. The reason for elevated metal content in the samples was due to the increased human influence on ground water [13].

\section{CONCLUSIONS}

The ground water sample from Pydibhimavaram industrial area was assessed for their quality in terms of their potential for drinking and irrigation. The results revealed that the ground water in the study area was neutral. The results indicated that all the samples have high electrical conductivity. The results also showed that in some areas chlorides, hardness, sulfates and nitrites concentrations were above the permissible limits. Samples of the Pydibhimavaram Industrial area exceed the permissible limits of BIS. The elemental concentrations of $\mathrm{Fe}, \mathrm{Ni}, \mathrm{Cd}$, and $\mathrm{Pb}$ were found to exceed the permissible limits of drinking water quality, whereas $\mathrm{Zn}$ concentrations are within the permissible limits. High trace metal concentrations were observed in ground water samples of Pydibhimavaram industrial area. This research may serve as a preliminary study to provide baseline information that may direct future water quality assessment studies in the study area.

\section{ACKNOWLEDGEMENTS}

The Authors are thankful to the Department of Science and Technology (DST), Ministry of Science\& Technology, New Delhi, Government of India, for granting necessary financial assistances to carry out this research project work.

\section{REFERENCES}

[1] T. Senthilnathan T. Parvathavarthini, K. V. Ssanthi, and M. George, "Evaluation of water quality assessment in an Industrial area," Indian Journal of Environmental protection, 405-408, 2012.
[2] Y.-P. Jiang and M. A. Zongren, "An evaluation of water quality from locations of Huangyang reservoir," Procedia Environmental Sciences, vol. 12, 2012, pp. 280-284.

[3] Bhandari, N. Singh and Kapilnayal, E.J. Chemistry, vol. 5, no. 2, pp. 342-346, 2008.

[4] A. K. De, Environmental Chemistry, Wiley Eastern publication, 1998.

[5] APHA, "Standard method for the examination of water and wastewater," American Public Health Association, Washington D.C., 1995.

[6] WHO, "Guidelines for drinking water quality," World Health Organization, Geneva, Swizerland. 1996.

[7] M. Ackah, O. Agyemang et al., "Assessment of groundwater quality for drinking and irrigation, The case study of Teiman-Oyarifa Community, GaEast Municipality, Ghana," in Proc. the International Academy of Ecology and Environmental Sciences, 2011, vol. 1, no. 3-4, pp. 186-194.

[8] World Health Organization, "WHO guidelines for drinking water quality," Geneva, Swizerland, 2004.

[9] E. Merian, Metals and Their Compounds in the Environment: Occurrence, Analysis and Biological Relevance, Wiley, USA, 1991.

[10] O. P. Neil, Environmental Chemistry, Chapman and Hall, London, UK, 1993.

[11] B. E. Prater, "The metal content and characteristics of Steework's effluents discharging to the Tees estuary," Water Pollution Control, vol. 74, pp. 63-78, 1975.

[12] M. R. G. Sayyed and M. H. Sayadi, "Variations in the heavy metal accumulations within the surface soils from the Chitgar industrial area of Tehran," in Proc. the International Academy of Ecology and Environmental Sciences, 2011, vol. 1, no. 1, pp. 36-46.

[13] P. Malleswara, G. Rao, R. Venkata, and S. Beebi, "Heavy metal transport in kolleru Lake Basin," Indian Journal of Environmental Protection, 2005, pp. 899-904.

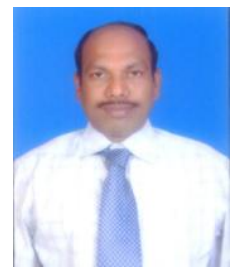

Gummadi Venkata Rao was born in Chintada, Jami Mandal, Vizianagaram, Andhra Pradesh India in 1972. He is currently working as a professor and the head of the Department of Civil Engineering in GMR Institute of Technology, Rajam, A.P, India. He received his Ph.D in civil engineering in 2009 from Andhra University College of Engineering, Visakhapatnam, Andhra Pradesh, India in the area of water resources engineering. He obtained the M.E. degree in 2002 from Andhra University College of Engineering, Visakhapatnam, Andhra Pradesh, India. He received his B.E degree from Chaitanya Bharathi Institute of Technology (CBIT) affliated to Osmania University, Hyderabad, Telangana, India in 1998. His areas of research interests are water resources engineering, environmental engineering, and salt water intrusion along the coastal belts and through estuaries. He is a member of Institute of Engineers, India. He has been doing research projects of worth around 1 crore rupees funded by the Dept. of Science and Technology (DST) and the Board of Research in Nuclear Sciences (BRNS), the Dept. of Atomic Energy, Government of India. $\mathrm{He}$ is one member of Research Advisory Board at GMR Institute of Technology. He has published more than 30 technical papers in various conferences and Journals.

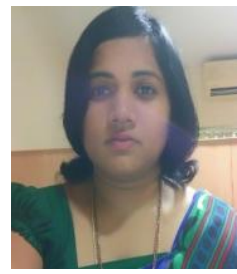

Polipalli Kalpana was born in Visakhapatnam, India in 1981. She is currently working in GMR Institute of Technology, Rajam, AP, India as an associate professor in the Department of Chemical Engineering. She received his Ph.D in chemical engineering in 2015 from Andhra University College of Engineering, Visakhapatnam, Andhra Pradesh, India in the area of textile dye removal using biomaterials. She obtained her masters degree in 2005 from Andhra University College of Engineering, Visakhapatnam, Andhra Pradesh, India. She received her B.Tech degree from Andhra University, Visakhapatnam, Andhra Pradesh, India in 2002. She is a member of Indian institute of chemical engineers, India. Her areas of research interests are water resources engineering, environmental engineering, pollution prevention methods, wastewater treatment. She has published more than 50 technical papers in various conferences and journals. 